pela profissão de médico até ao ponto de fantasiar estar num hotel ou em qualquer lugar público onde preferiria assinar "dr. Mário" em vez de simplesmente "Mário".

O capítulo sobre Mário denota esta comunhão entre literatura e medicina como algo especial porque esta serve muitas vezes como alimento para a expressão literária. Nestes momentos, o leitor sente um apelo da parte de Scliar para que o médico adote um papel mais humanista no exercício da sua profissão. Para um médico e literato sensível, a presença do ser humano se assenta não apenas no corpo, mas também na alma do paciente, a zona onde, segundo o médico-escritor norte-americano, William Carlos Williams, "o médico tem a preciosa oportunidade de ver as palavras nascerem". Aí o poder das metáforas que, segundo Susan Sontag, nasce dos mitos e das fantasias sobre a doença e freqüentemente representa uma "consciência coletiva" face a angústia ou depressão que atinge um grande número de pessoas. Certamente é o caso do escritor William Styron que, com seu livro sobre a própria depressão, Darkness visible, atingiu uma densa expressão com metáforas penetrantes como a de uma "tempestade uivando no cérebro". Com esta obra, Styron consagrou o papel importante da literatura porque sublinhou a necessidade de encarar a doença de modo enfático para que seu tratamento e cura possam ser finalmente realizados.

Ao finalizar o livro com um texto do escritor brasileiro Caio Fernando Abreu, que faleceu de Aids em 1996, Moacyr Scliar indiretamente faz outro apelo para a necessidade de maior conscientização perante a realidade desta doença ubíqua e, sobretudo, em face da cruel hipocrisia que atrasou pesquisas valiosas e prejudicou uma cura mais rápida. Assim, de forma realista, o livro reitera o drama brutal da doença, a vulnerabilidade da medicina e, nesse caso, a perda para a literatura. Em vez de ser uma simples apologia, este livro estabelece um balanço entre os sucessos e as derrotas da medicina. Ao mesmo tempo, como se sentisse obrigado a exercer o ofício de médico-escritor para afastar o desespero e a dor, Moacyr Scliar apropriadamente termina o texto com um to- que humanista ao empregar estas palavras de Caio Fernando Abreu: "A vida grita. E a luta continua."

Nelson H. Vieira

Pesquisador da Brown University

\section{TRIBUTO A VÊNUS: A LUTA CONTRA A SÍFILIS NO BRASIL, DA PASSAGEM DO SÉCULO AOS ANOS 40}

Sérgio Carrara

Rio de Janeiro, Editora Fiocruz, 1996, 327 p.

O trabalho de Carrara aborda as estratégias de combate à sífilis no Brasil ao longo de um período de quase cinqüenta anos, do final do século XIX à década de 1940. Operando metodologicamente a partir da perspectiva da história social, o autor analisou uma série extensa de documentos, produzindo um retrato a um tempo abrangente e profundo do seu objeto de estudo.

Este objeto, aparentemente singelo, desclobrou-se numa série de inter-relações, configurando um campo amplo e complexo. Um primeiro ponto a ser observado diz respeito à própria sífilis; ainda que conhecida por centenas de anos já àquela época, a sífilis parece recrudescer, senão em termos epidemiológicos, pelo menos em termos de sua percepção por parte da coletividade. Vários fatores cooperam na retomada de importância deste mal venéreo; a configuração moderna da doença, atribuída a um agente transmissível na esteira dos triunfos alcançados pela bacteriologia em fins do século passado (ainda que o treponema só venha a ser identificado em 1905) e prontamente transformado em objeto de um teste laboratorial, a reação de Wassermann, constituiu uma ameaça capaz de alcançar vários órgãos e sistemas do corpo e mesmo a descendência dos indivíduos acometidos pelas suas formas "hereditárias" (hoje diríamos congênitas), espectro pairando por sobre toda a população. 
Há um conjunto de médicos que, ao mesmo tempo que estruturam o inimigo - a sifilis credenciam-se como corpo de especialistas a combatê-la - os sifilógrafos - , dialogando com o conjunto da sociedade, a qual pretendem disciplinar; com o Estado, ao qual pretendem se associar; e com sua contraparte nos países centrais, junto aos quais pretendem se credenciar como interlocutores acadêmicos.

Estes objetivos estratégicos se desenrolam num conjunto de táticas bastante eficazes, que asseguram a introdução do combate à sífilis na agenda nacional e os espaços pretendidos, tanto em termos estritamente políticos quanto acadêmicos. Por um lado, a ameaça da sífilis é constantemente brandida, recorrendo-se freqüentemente a dados numéricos assustadores, ainda que precariamente sustentados, estendendo indefinidamente o número de pessoas acometidas pela doença. Por outro, constroí-se uma sífilis brasileira, peculiar a este país e que só se desvela por inteiro aos seus especialistas. Por fim, há nas primeiras décadas deste século uma combinação do discurso do combate à sífilis com a visão higienista que privilegiava um enfoque eugênico, na conclamação ao combate à "degeneração da raça", da qual a sífilis seria a um tempo causa e conseqüência. Some-se a estas estratégias discursivas a caracterização clínica multiforme da sífilis, como já mencionado, e tem-se o panorama da ampla intervenção que se desenrola no período estudado, criando normas e regulamentos para a prostituição; para o tratamento e controle dos infectados; para controle pré-nupcial dos candidatos ao casamento; para a vigilância estrita dos praças nos quartéis; para um sem-número de campanhas de comunicação; toda uma panóplia de controle disciplinar segundo o modelo descrito por Foucault - não por acaso, um dos referenciais teóricos do trabalho de Carrara.

É na descrição desta montagem que Carrara introduz outro referencial teórico importante para sua compreensão: a pers-pectiva do processo civilizador, segundo Norbert Elias. O processo de construção e combate à "sífilis-inimigo" (expressão do autor) se dá simultaneamente ao processo de construção da nação brasileira; o país onde se deveria "pensar sifiliticamente" se define também pelas intervençôes organizadas do aparato médico do Estado em organização.

Ao encerrar seu livro, o autor ainda aponta direções possiveis para desdobramentos futuros da linha de pesquisa iniciada. Destacamos em particular os paralelos apontados com a situação atual do enfrentamento da epidemia de HIV/ Aids, que efetivamente se impõem. Neste item em particular, talvez seja possível apontar uma pequena discordância com um dos possíveis desdobramentos neste último processo, apontado por Carrara: a perspectiva que, simetricamente ao papel desempenhado pela sífilis na construção do Estado-Nação, a Aids poderia marcar sua derrocada, dado o papel político alcançado pela rede de organizações nãogovernamentais (Ongs) que se implantou procurando, parafraseando o autor, suprir as dificuldades na atuação de Fstados nacionais em crise. Se observarmos, ao menos no caso brasileiro, como parte significativa clas Ongs na área de HIV/Aids tem sido cooptada pelas próprias instâncias governamentais através de um programa financiado com recursos externos, a contribuição destas organizações para o esvaziamento do papel do Estado deve ser relativizado, ao menos.

O trabalho de Carrara é, de todo modo, um marco importante no estudo da história social das doenças no Brasil, e uma referência fundamental - senão obrigatória - para este campo de pesquisa. Contribui ainda para isso a adoção de pequenos cuidados que em muito facilitam sua utilização como texto de referência, como a utilização de gráficos temporais assinalando marcos relevantes da história estudada, ou ainda a presença do índice onomástico.

Em suma, trata-se do produto sólido de um investigador maduro, que fica agora devendo os desdobramentos que nos acenou.

Kenneth R. de Camargo Jr.

Professor adjunto do Instituto de Medicina Social cla Universidade do Estado do Rio de Janeiro Rua São Francisco Xavier, 524/7 bl. D Rio de Janeiro - RJ e-mail: kenneth@vmesa.uerj.br 